\title{
Financial Potential and Tools for Commercialization of Biotechnology Projects in the Sustainable Development System
}

\author{
A. A. Kasatova ${ }^{1}$, V. I. Vagizova ${ }^{2}$, I. A. Kokh ${ }^{3}$ \\ ${ }^{I}$ Department of financial markets and financial institutions, Kazan Federal University, Kazan, Russian Federation, \\ ${ }^{2}$ Higher School of Business, Kazan Federal University, Kazan, Russian Federation \\ ${ }^{3}$ Department of financial markets and financial institutions, Kazan Federal University, Kazan, Russian Federation \\ Correspondence: A. A. Kasatova, Russian Federation, Kazan, Kosmonavtov Street, $42 a$.
}

\begin{abstract}
The article focuses on the need to commercialize biotechnology in agriculture and sources of its funding. Financing tools are arranged as per the stages of implementation of biotechnology projects. The study analyzes the results of innovative activities of enterprises in the agroindustrial sector of the economy, and suggests measures to improve commercialization of biotechnology in agriculture in the context of implementation of the principles of sustainable development.
\end{abstract}

Keywords: Financing tools of commercialization, biotechnology, innovative activity, sustainable development

\section{INTRODUCTION}

One of the key areas of innovative development of the modern Russian economy is biotechnology. According to the estimates, in 2025 the global biotechnology market will reach a level of USD 2 trillion; growth rates in individual market segments range from 5-7 to $30 \%$ per annum. Russia's share in the biotechnology market is less than $0.1 \%$. The consumers of biotechnology products are mainly well-developed countries: the USA, Canada, Japan, and the European Union. However, over the current decade, developing countries have joined the technological race: China, India, and Brazil implement large-scale development programs across the entire range of biotechnology.

The main areas of biotechnology in Russia are:

- industrial bioproducts,

- biotechnological agricultural products,

- biofuel and bioenergy,

- food bioproducts,

- biological environmental systems,

- biotechnological systems and products for the forest sector, and

aquabioculture.

In the near future, the highest demand for biotechnology will be observed in agriculture, food industry, production of chemical agents and biofuel. Use of biotechnology in agriculture is focused on sustainable development of agricultural production, settlement of food security issues, obtaining high-quality and eco-friendly foods, processing agricultural waste, and restoring soil fertility. Therefore, one can distinguish the following innovative biotechnological agricultural products, which will result in high yields, increase resistance to environmental conditions, improve taste of products, and balance nutrients and vitamins. These are:

- new varieties of agricultural plants,

- new biotechnological forms of trees with predetermined characteristics,

- strains of microorganisms and microbial consortia designed to create symbiotic plantmicrobial communities that provide plants with mineral substances and ensure their protection against pathogens,

- plants and animals - biofactories for bioproducts for industrial and medical purposes,

- new bacterial spores for farm animals,

- feed preservatives and silage starter cultures, and

- balanced feed and premixes.

Thus, biotechnology in agriculture is one of the most significant and rapidly developing technological areas. Its intensive development is due to the need to ensure food security, to preserve resource potential, and to increase the life expectancy of the population.

\section{LITERATURE REVIEW}

The basis for development of the agricultural biotechnology market is dissemination and implementation of ideas, developments and technologies on the market. This type of activity is called commercialization. There are many interpretations of this concept. In this work, we considered the basic ones. 
According to the definition of V. I. Mukhopad [11], commercialization is a process of conversion of the property (innovation) item into profit using commercial means.

E. A. Monastyrny [10] and Ya. N. Grik defined innovation commercialization as acquisition of income from its sale or use in own production.

G. Kozmetsky [8] describes commercialization as a process, with the help of which results of scientific research and development activities (R\&D) are timely transformed into products and services on the market.

N. V. Shumyankova [12] considers commercialization as a form of commercial transfer, upon which the consumer (buyer) acquires the right to use innovations in research, production, operation, or consumption in order to profit from their use, and pays a fee to the innovation owner in one form or another in the amount determined by the terms and conditions of a license (or other) agreement between them.

It should be noted that the transfer means a transfer of scientific and technical knowledge used in the areas of material production and service rendering for its further development. Transfer is the basis of commercialization. Therefore, the difference lies in the fact that gaining of benefits is an indispensable condition for commercialization. Thus, commercialization is often understood as a commercial transfer.

P. N. Zavlin [16] considers commercialization in terms of the concept of innovation life cycle, in particular, as one of its phases.

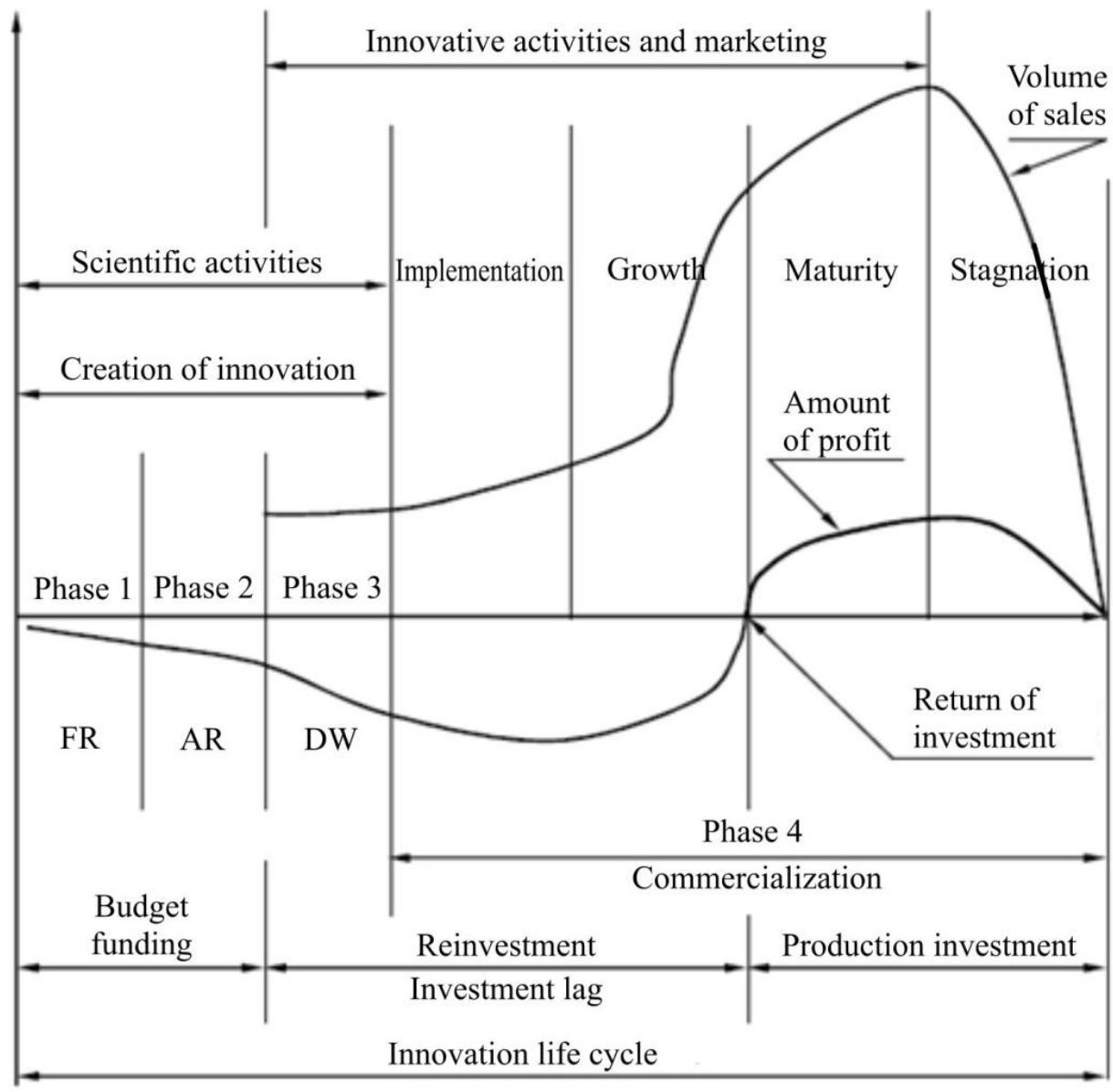

Figure 1: Concept of Innovation Life Cycle of P. N. Zavlin

According to P. N. Zavlin [16], the innovation life cycle includes five stages divided into four phases - fundamental research, applied research, development work, which constitute the stage of innovation creation, and the phase of commercialization, which covers the remaining stages - from "introduction" into production and to "downturn".

A. A. Trifilova [14], on the contrary, connects commercialization only with the innovation process. 
International Journal of Engineering Research and Technology. ISSN 0974-3154, Volume 13, Number 11 (2020), pp. $3659-3666$

(C) International Research Publication House. https://dx.doi.org/10.37624/IJERT/13.11.2020.3659-3666

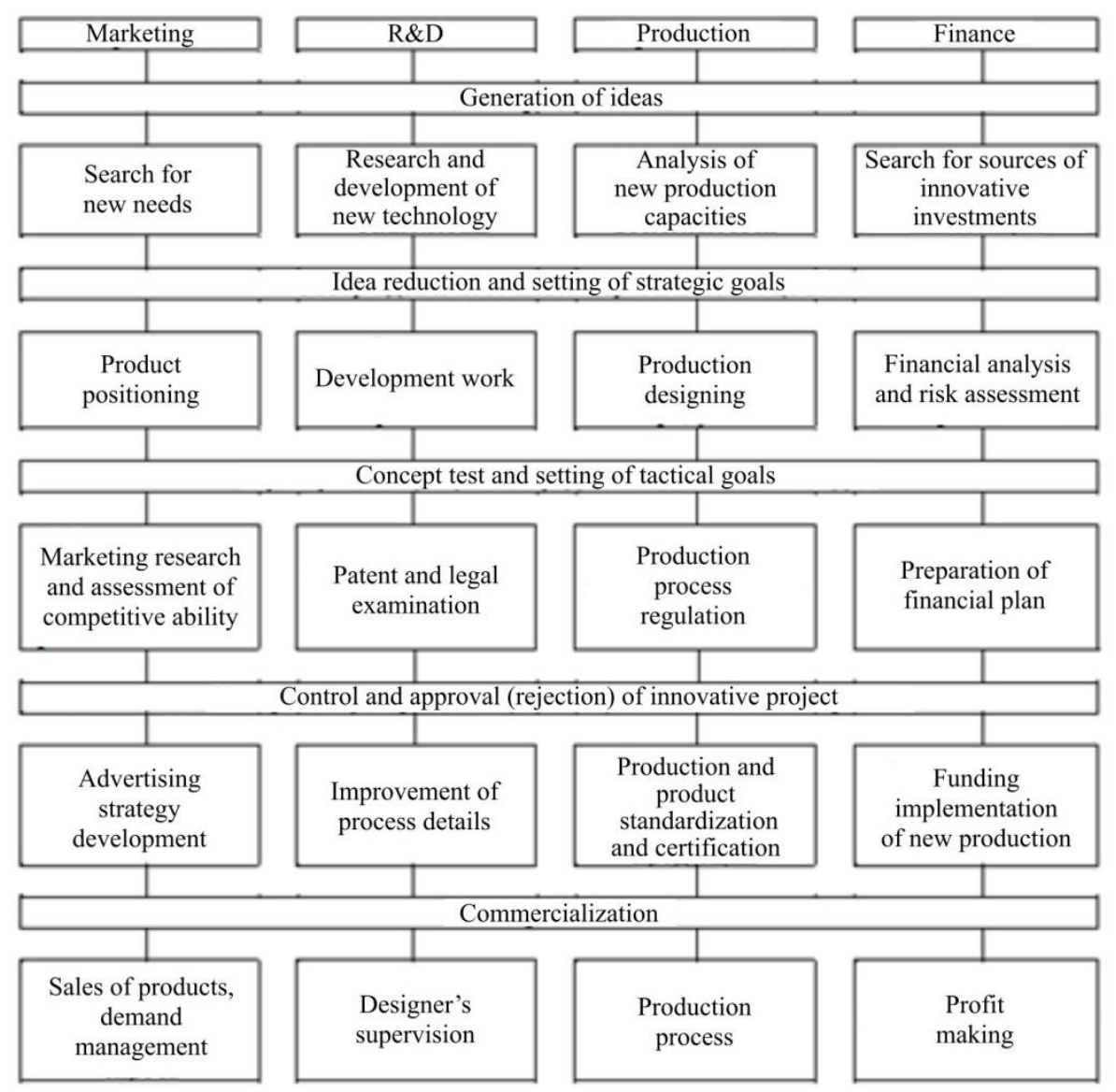

Figure 2: Concept of Innovation Life Cycle of P. N. Zavlin

Within the framework of the concept of A. A. Trifilova [14], commercialization is the last step in a clearly sequential process. The commercialization process is presented in a narrower sense, but unlike P. N. Zavlin's [16] concept of the life cycle, according to which, due to many stages of innovation development, the terms of commercialization can be represented only in the long term, it is not extended in terms of time.

In general, having studied all the definitions, the commercialization of the biotechnology market can be represented as the process of biotechnologies introduction to the market, starting from the emergence of an idea to its implementation in the market.

\section{RESEARCH QUESTION}

The process of biotechnology introduction to the market requires raising funds. The following participants can be engaged to finance biotechnology:

1. Founders and entrepreneurs. They usually use all money that they can afford as well as non-financial contributions in the form of, for example, low wages or their complete absence, work at home (without rent), etc. Reliance on these non-financial assets can increase their effective participation in equity. New investors expect significant contributions from the founders as this shows their loyalty to the project.
2. Business angels (informal investors). Affluent private investors - 75\% of them invest USD 15,000 to USD 150,000, and sometimes up to USD 250,000 when they co-finance with others (the "syndicate" investment). They usually invest locally and in the projects that they understand. They often choose the "active participation" approach for their investments, that is, they take part in the management of the company and/or act as an assistant consultant.

3. Venture capital. They look for investment opportunities in companies with great growth prospects. They are usually not interested in amounts less than USD 250,000. They create added value (most often, by participating in the management of the company), and not just provide financial assistance. Should venture capital be attracted, there is no cash outflow in the form of interest on loans or dividends to investors before "withdrawal from the company" (selling their shares).

4. Banks. They provide regular banking services. Loans and loan guarantees range from several thousand to millions of dollars. They provide investment services.

5. Public sector. Most often, it finances performance (completion) of research. It provides grants and bonuses. Sometimes it provides bank guarantees (for obtaining loans) or preferential credit conditions.

The main forms of funding for the biotechnology market are:

- state funds, as a rule, provide grants or interest-free loans, 
- banks that provide loans, and

- venture capital (private equity investments) usually prefers to provide capital through acquisition of a company's share (stocks).

Which of these forms are more suitable for each particular case depends on many factors: the stage of development, at which the project is, the size of the innovative company, the amount of funds required, etc.

At the research stage, funds are usually received in the form of grants from:

- The public sector - federal programs, regional innovative development programs, international programs.

- The corporate sector - industrial/commercial companies, industrial research associations, charitable organizations (when research is socially oriented, for example, in the health care sector).

Banks or private investors are unlikely to be interested in investing at this stage.

At the development stage, the project is funded through:

- Seed funds - venture capital funds ready for investments in technologies preceding the start up stage and followed by further investments if/when a company is formed during the project implementation. Pre-start up financing may take the form of loans, which are converted into the authorized capital when the company is formed.

- Venture capital - may be interested when an established company needs additional financing for implementation of a particular project.

The introduction stage (start up) involves the following:

- Business angels. They can provide the authorized capital and "active participation" - advice and assistance — to a newly formed company. This source is more suitable when a relatively small amount is requested and when the project in question is not in the field of high technology.

- Venture capital. Although most venture funds focus on major transactions, there is also some interest in providing start-up capital. As a rule, venture capitalists have extensive experience and the ability to provide assistance in the field of management.

- Public sector: may provide grants or other gratuitous financing to cover start-up and capital expenses. State-owned venture funds may be willing to intervene when, for example, significant prospects for employment open up.

- Corporate financing can also be obtained from industrial or commercial companies that look for development opportunities. These companies are potential buyers of the new company.

At the stage of operation, the project has already entered the market and the banks and all types of venture funds may be interested in it. This is also the stage when the company's management can consider sale of a company's share (or issue of new shares) as a way to obtain additional capital.
Therefore, financing of biotechnology projects primarily depends on the stage of development, at which they are. Moreover, these sources are not always sufficient for commercialization.

\section{RESEARCH METHODOLOGY}

The innovative activity of large and medium-sized agricultural entities is characterized by low intensity.

Thus, in 2016, the share of enterprises implementing technological innovations in their total number amounted to only $3.4 \%$. For comparison, in industrial production the same indicator reaches $9.2 \%$. Thus, in comparison with a number of European countries, Russian agricultural producers noticeably lag behind in terms of innovation activity. In some cases the gap exceeds tenfold value (Norway - 59.8\%; the Netherlands - $48.3 \%$; Denmark - $40.8 \%$; and Spain $8.6 \%)$.

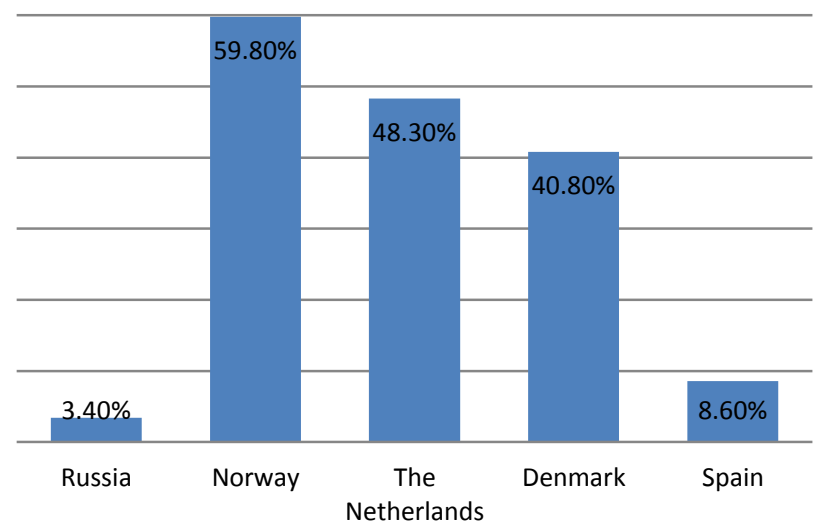

Figure 3: Relative Share of Enterprises Implementing Technological Innovations per Country over 2016, \%

The key resulting characteristic of the innovative activity of enterprises reflecting their contribution to the country's economy is production of products based on new and improved technologies.

In 2016, the volume of innovative goods, work, and services of agricultural enterprises reached 22.2 billion Rubles, twothirds of which were in the field of livestock breeding. In general, the contribution of innovative products into development of Russian agriculture is small: its relative share in the total volume of shipped goods, performed work and services amounted to only $1.4 \%$ (in industrial production $8.4 \%$ ). In a number of European countries, about a tenth of the output of agricultural enterprises is classified as "innovative" (Spain - $12.7 \%$; Denmark - $11.6 \%$; and the Netherlands - $9.2 \%)$. 


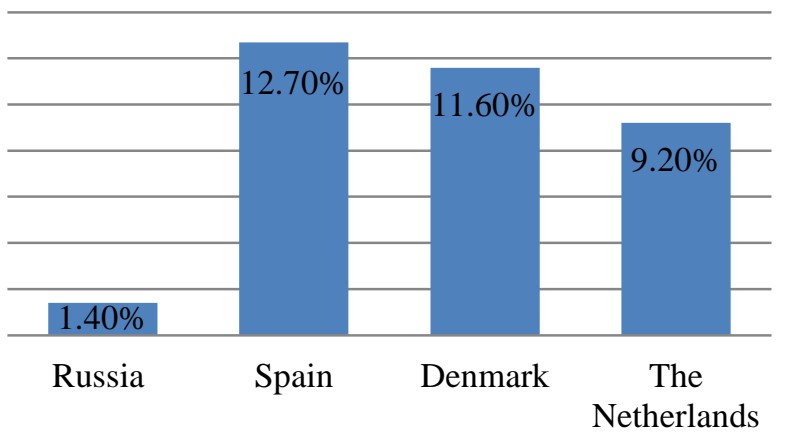

Figure 4: Volume of Innovative Goods, Work, and Services of Agricultural Enterprises by Country over 2016, \%.

The maximum value of the level of innovative activity in agriculture was recorded in the field of livestock breeding $(3.9 \%)$ and crop production $(3.7 \%)$ (Table 1$)$. The scale of innovation processes in other agricultural sectors is insignificant and they do not significantly affect general trends.

Table 1: Principal Indicators of Innovative Activity of Agricultural Enterprises in 2016

\begin{tabular}{|c|c|c|c|}
\hline Index & $\begin{array}{c}\text { Agriculture - } \\
\text { total }\end{array}$ & $\begin{array}{c}\text { Crop } \\
\text { production }\end{array}$ & $\begin{array}{l}\text { Livestock } \\
\text { breeding }\end{array}$ \\
\hline $\begin{array}{c}\text { Level of innovative } \\
\text { activity, } \%\end{array}$ & 3.4 & 3.7 & 3.9 \\
\hline $\begin{array}{l}\text { Expenses for technological } \\
\text { innovations, million Rubles: } \\
\text { - research and development } \\
\text { costs, } \% \\
\text { - expenses for acquisition of } \\
\text { machinery and equipment, } \%\end{array}$ & $\begin{array}{c}14,963.3 \\
12.9 \\
50.3\end{array}$ & $\begin{array}{c}3,276.1 \\
\\
15.5 \\
40\end{array}$ & $\begin{array}{c}5,669.3 \\
\\
15.4 \\
77.3\end{array}$ \\
\hline $\begin{array}{l}\text { Intensity of expenses for } \\
\text { technological innovations, } \%\end{array}$ & 0.9 & 1.1 & 0.6 \\
\hline $\begin{array}{c}\text { Volume of innovative goods, } \\
\text { work, and services, million } \\
\text { Rubles }\end{array}$ & $22,222.9$ & 6,542 & $14,936.5$ \\
\hline $\begin{array}{l}\text { Relative share of innovative } \\
\text { goods, work, and services in } \\
\text { the total volume of shipped } \\
\text { goods and performed work, }\end{array}$ & 1.4 & 1.1 & 1.6 \\
\hline
\end{tabular}

\begin{tabular}{|l|l|l|l|}
\hline$\%$ & & & \\
\hline
\end{tabular}

Expenses for technological innovations in agriculture do not meet the objectives of intensive development of the industry. In 2016, their volume amounted to about 15 billion Rubles, and the crop production and livestock breeding accounted for the major part of it (almost $80 \%$ ). The intensity of expenses for technological innovations (that is, their share in the total volume of shipped products) amounted to $0.9 \%$, which is a half of the average value in industrial production. According to this indicator, domestic agriculture is also inferior to that of the European countries (in the Netherlands - 8.5\%; Norway - $2.4 \%$; Denmark - $1.9 \%$; and Spain - $1.3 \%$ ).

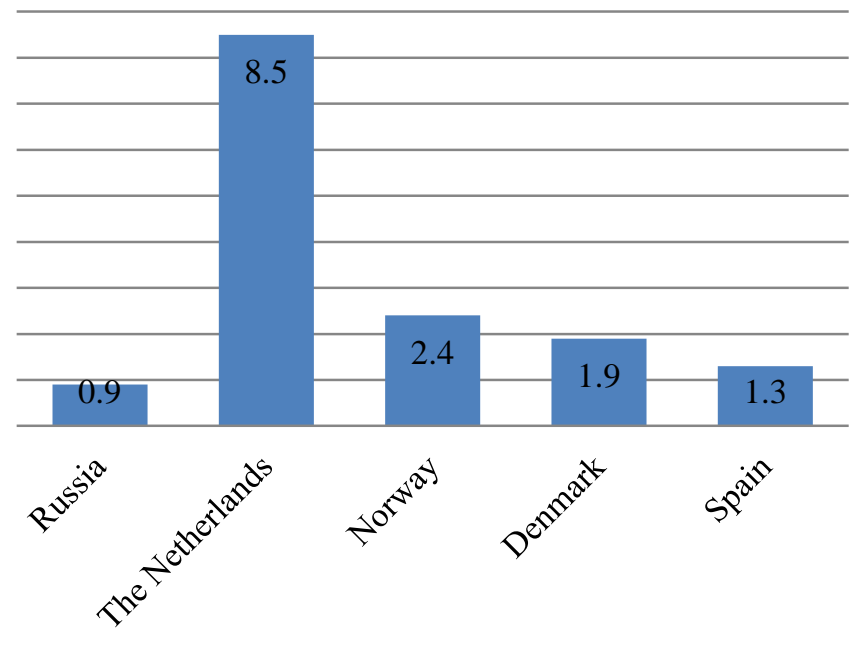

Figure 5: Expenses of Technological Innovations in Agriculture by Country over 2016, \%.

The structure of expenses for technological innovations in agriculture is dominated by investments in acquisition of machinery and equipment $(50.3 \%)$, which is also characteristic of the industrial production sectors. 


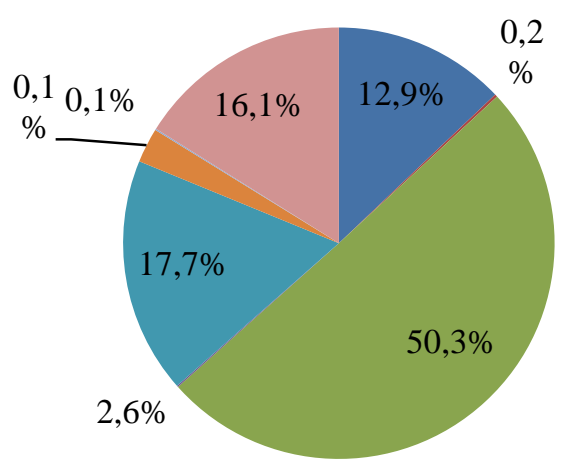

Research and development

Design

Acquisition of machinery and equipment

Acquisition of software

Engineering

- Staff education and training

Marketing research

Other expenses

Figure 6: Structures of Expenses for Technological Innovations of Agricultural Entities by Type of Innovative Activity over $2016, \%$.

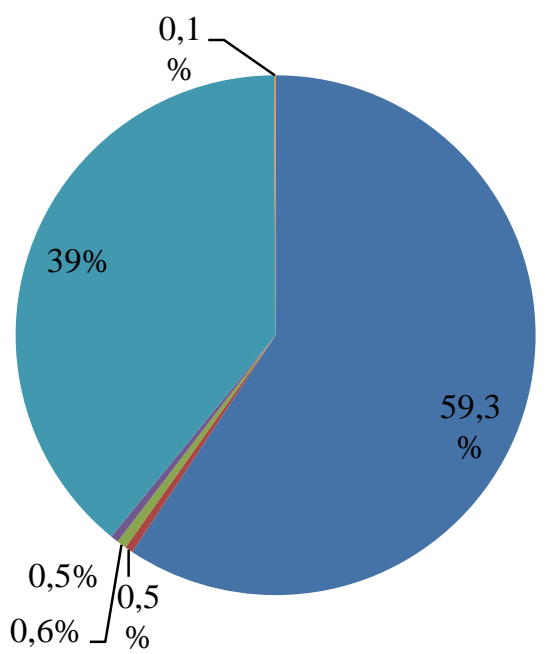

Own funds

Federal budget

Budgets of the constituent entities of the Russian Federation and local budgets

Foreign investments

- Credits and loans

Other

Figure 7: Structure of Expenses for Technological Innovations of Agricultural Entities by Source of Funding over $2016, \%$.

Research and development costs make up only one eighth (23.6\% in industrial production), reflecting the low demand of agribusiness for the results of scientific and technical activities.

Agricultural entities are characterized by a high share of engineering expenses $(17.7 \%)$, which is twice as high as the corresponding value in the industrial production. In crop production, this indicator reaches $37.5 \%$. The share of costs for other "intellectual" types of innovative activities acquisition of new technologies, software, marketing research, staff education and training - is insignificant (less than $3 \%$ in total).

Most innovative agricultural entities (about $70 \%$ ) carry out technological innovations with the involvement of third parties, which is often due to insufficiency or lack of their own research base.

Innovation activity is mainly implemented at the expense of enterprises' own funds, accounting for $59.3 \%$ of the total structure of expenses for technological innovations.

Credits and loans take the second place among sources of financing (39\%), since agricultural enterprises often do not have sufficient financial resources to make long-term investments. The contribution of other sources is minimal: budget support in total provides only $1.1 \%$ of the expenses for technological innovations (including $0.5 \%$ from the federal budget; $0.6 \%$ from the budgets of the constituent entities of the Russian Federation and local budgets); foreign investment, $0.5 \%$.

\section{RESULTS}

The results of innovative activities, according to agricultural enterprises, are reflected in increased yields, productivity of livestock and poultry, and aquaculture facilities; improvement of product quality (about one third of innovative enterprises 
noted high importance of each of these results). Moreover, there is an important role of innovations in increasing production capacities $(22.9 \%)$; conservation, restoration and improvement of fertility of agricultural land $(22.4 \%)$. However, the analysis shows that agricultural enterprises in Russia do not develop and do not use new developments in the field of biotechnology, but invest the raised funds mainly in new machinery and equipment. Efforts and investments should be directed primarily to the production of more marginal products with an innovative component. These are organic, functional products and highly processed agricultural products, not gross agricultural raw materials.

\section{CONCLUSIONS}

The current situation in Russia shows:

- low productivity of agriculture

- critical lag of the research, and production and technological base in the field of biotechnology

- low demand for practical development

- insufficient business investment in development of biotechnological production

- high barriers to entry into the global market for biotechnological products

- risk of turning the country into a raw material base for world leaders in the biotechnology market.

Therefore, the following activities may be proposed:

- improvement of state financial support for research and development through implementation of state lending, state guarantees for bank loans, tax benefits, accelerated depreciation, export-import quotas to support the national high-tech product

- removal (reduction) of tax law barriers and restrictions

- stimulation of private investment through creation of patent and venture companies

- stimulation of public-private partnership in the field of investment in innovative projects

- support for national innovation producers through creation of a national brand development program, support for small and medium-sized innovative businesses

- selection of highly profitable innovations for efficient commercialization

- development of a mechanism for innovative mediation between innovators, and production and business communities

- state financial support at the first stages of the innovation process, participation in formation of the results of scientific activities including bringing to pilot development

- increase in capitalization of innovative enterprises through development of a strategy for the search for additional sources of financing

- state equity participation in newly created enterprises as a guarantor of stability and co-financing

- comprehensive co-investment of cluster projects within the framework of interaction of regional and federal budgets through administration of federal subsidies, creation of own items in regional target and targeted investment programs, taking into account benefits for residents and for the purpose of experience sharing

- creation of the state "innovation infrastructure" and conditions for implementation of efficient commercialization

- financing research on a competitive basis

- integration of science and technology policies with industrial policies

- expansion of cooperation between scientists and industry (entrepreneurs and research institutes)

- stimulation of innovation transfer

- establishment and development of new holding companies.

All these measures will help develop the biotechnology market in agriculture and support the commercialization mechanism.

\section{REFERENCES}

[1] Antonets, V.A., Nechaeva, N.V. Fundamentals of Technology Commercialization. Training material for the Innovative 130 Activities in the Scientific and Technical Field. Commercialization of Research and Development Results advanced training program.Nizhny Novgorod: NNGU, 2007, - 108 p.

[2] Forecast of Scientific and Technological Development of Russia: 2030 / Edited by L. M. Hochberg. Moscow: Ministry of Education and Science of the Russian Federation, Higher School of Economics National Research University, 2014. - 244 p.

[3] Integrated Program for Development of Biotechnology in the Russian Federation for the period until 2020

[4] Kasatova, A., Postaliuk, M., Khasanova, A. The Decomposition Analysis Institutional Support of Traditionalization and Innovatization of Russian Economy. Academy of Strategic Management Journal, 2016, 15(S2), pp. 100-110.

[5] Kasatova, A., Postaliuk, M., Khasanova, A., Budovich, M. The Innovatization of Management Institutions in the Russian Economy. Academy of Strategic Management Journal, 2016, 15(S2), pp. 111-120.

[6] Kasatova, A.A. Efficient Forms of Interaction between Financial and Agricultural Sectors of the Russian Economy. Kazan Economic Bulletin, 2014, pp. 16-22.

[7] Kasatova, A.A., Vagizova, V. I., Tufetulov, A.M. Stages of Biotechnology Commercialization in the System of Interaction between Financial and Innovative Industrial Structures. Academy of Strategic Management Journal, 2016, 15 (Special Issue 1), pp. 198-204.

[8] Kozmetsky, G. Challenge of Technological Innovation 
on the Threshold of New Era of Global Competition. Technology Transfer and Efficient Implementation of Innovations / Edited by N. M. Fonstein. - Moscow: ANKh, 1999. - 296 p., P. 11.

[9] Macroeconomic Condition of Interaction between Financial Sector and Agribusiness. Investment Management and Financial Innovations International Research Journal, 2014, 4(11), 175-183.

[10] Monastyrny, E.A., Grik Ya.N. Resource-Based Approach to Building Business Processes and Commercialization of Developments. Innovations, 2004, 7. P. 85.

[11] Mukhopad, V. I. Commercialization of Intellectual Property. Moscow: Magistr, 2010, 511 p., P. 52; 73.

[12] Shumyankova, N.V. Commercialization of Results of Scientific and Technical Activity. - Moscow: National Institute of Business, 2005. - 294 p.

[13] Strategy of Innovative Development of the Russian Federation for the period until 2020 - Approved by Resolution No. 2227-p of the Government of the Russian Federation dated December 8, 2011.

[14] Trifilova, A.A. Analysis of Innovative Processes. Law. Economics. Marketing, 2005. 5, 99.

[15] Tufetulov, A.M. Bioeconomy's Potential for Development and Commercialization Opportunities for Biosphere Projects in Russia. A. A. Kasatova, V. I. Vagizova, A. M. Tufetulov. Academy of Strategic Management Journal, 2016, 15 (Special Issue 1), pp. 225-232.

[16] Zavlin, P.N., Ipatov, A.A., Kulagin, A.S. Innovative Activities in the Market Conditions. - St. Petersburg: Nauka Publishing House, P. 37. 